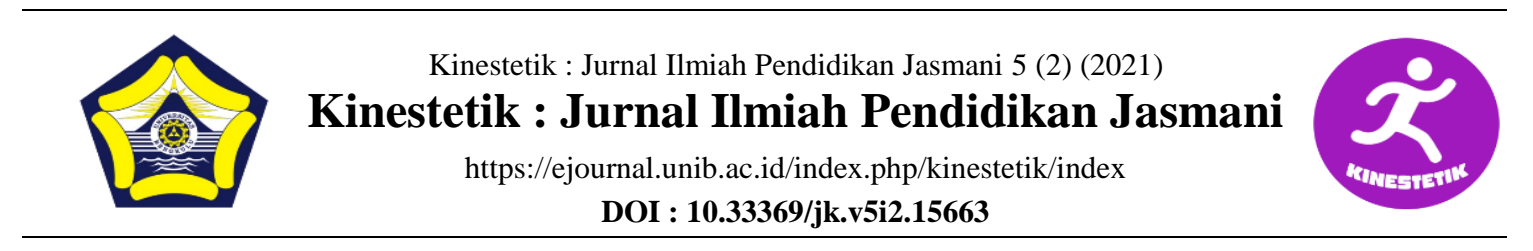

\title{
THE EFFECT OF OBESITY AND FLEXIBILITY TOWARD WOMEN'S BODY FAT IN PRODUCTIVE AGE AT LARASATI GYMNASTIC SEMARANG MEMBER
}

\section{Eva Faridah}

Physical Education, Health and Recreation, Faculty of Sport Sciences, Universitas Negeri Medan, Indonesia.

\begin{tabular}{l} 
Article Info \\
\hline Article History : \\
Received : April 2021 \\
Revised : May 2021 \\
Accepted :June 2021 \\
Available online : June 2021
\end{tabular}

Keywords:

Body Fat, Flexibility, Obesity

\begin{abstract}
Obesity is an body fat increase. Overweight is a relative body weight increase when compared to the standard. Overweight then became a term that represented "obesity" both clinically and epidemiologically. Flexibility is the effectiveness of a person in adjusting himself to all activities with stretching the body in a wide area of the joint. The design used in this study is a $2 \times 2$ factorial. It is explained about factorial experiments that what is measured is not only the influence of the main factor of each independent variable on the dependent variable, but also the influence of the interaction between the independent variables. The population in this study is the 50 members of Larasati gymnastics in Semarang, who in productive age women between 30-40 years. The number of samples is quite representative (representing) for the large population in this study. The sampling technique in this study was using purposive sampling, which is a sampling technique determined by giving equal opportunity to each member of the population as a sample, namely the number is adjusted to the member of the subject in each group, the experimental group of obesity type pear and apple type obesity control group. Based on the results of the research achieved, it turns out that women who have high flexibility have a large reduction in fat if they have the apple type of obesity. Women who have high flexibility with apple obesity type have a better decrease in body fat than women with low flexibility and have pear obesity type. Fcount $=6.962>$ Ftable $=3.11$. The effectiveness that is applied to reduce body fat is influenced by the type of high flexibility and type of low flexibility of those women.
\end{abstract}

Corresponding address : Jalan Willem Iskandar / Pasar V, Medan,

Sumatera Utara

*Corresponding email : evafaridah@unimed.ac.id
ISSN 2685-6514 (Online)

ISSN 2477-331X (Print) 


\section{INTRODUCTION}

Obesity is a body fat increase. Overweight is a relative body weight increasing when compared to the standard. Overweight then became a term that represented "obesity" both clinically and epidemiologically. Meanwhile, central obesity is a body fat increase, which is located more in the abdominal area than in the pelvic area, thighs and arms.

A study entitled "Ovulation Induction by Metformin Among Obese and Non-Obese Women with Polycystic Ovary Syndrome", the results of the study stated that 109 women with PCOS who were prescribed metformin P3 months were included in the study, nearly $60 \%$ of women included in this study were obese, possibly ovulation among obese women with PCOS was $77.9 \%$ (likelihood ratio = $0.221 .95 \%$ CI $0.052-0.947, \mathrm{P}=0.042$ ) less than that in their obesity record. Women with obesity are interrelated, the older a woman is, many are obese, because the reproductive hormone (estrogen) follows age (Al-Ruthia, AlMandeel, \& Alsanawi, 2017).

A study entitled "In Utero Programming and Early Detection of Cardiovascular Disease In The Offspring Of Mothers With Obesity", the results of the study described insulin resistance as increased leptin levels, chronic inflammatory conditions, impaired sympathetic tone and epigenetic modifications contribute to a suboptimal nutritional environment and hemodynamic changes. Deviated cardiomyocyte development, impaired endothelial cell relaxation and an atherogenic lipid profile put children at risk of developing endothelial cell dysfunction. Improve early detection of atherosclerotic diseases, prevention and treatment strategies (Van De Maele, Devlieger, \& Gies, 2018). The study entitled "Obesity as a Risk Factor for Dengue Shock Syndrome" stated that obesity is a risk factor for shock in DHF (Dengue Hemorrhagic Fever), the risk of SSD (Dengue Shock Syndrome) in obese children is 4.9 times greater than that of non- obese (S, Arhana, Suandi, \& Sidiartha, 2017). Regular physical activity can help control body weight and reduce the risk of obesity by up to $50 \%$, compared to individuals who do not do enough physical activity. Thus, obesity is multifactorial and various recent findings related to obesity causes the pathogenesis of obesity to continue to develop. If the individual does not take care of his body health. Balancing the health of the body with sports activities and paying attention to what eating patterns are consumed, being careful with ready-to-eat food, because the impact is bad for health. Anticipating as early as possible with a health check, weighing is also one of the solutions to maintain health (Endang, Ratu, \& Dewi, 2010).

(Marlinda, 2015) Kinds of Obesity In general, obesity can be divided into two major groups. 1. Obesity Type Android or Central Type (Apple) Fat-shaped body like a barrel, the stomach bulges forward, many are found in men. This type tends to develop coronary heart disease, diabetes and stroke. The study entitled "HbA1c Levels and Lipid Ratio in Adult Women with Central Obesity", the results of this study showed that there were differences in $\mathrm{HbA1c}$ values and lipid profiles between groups of adult women with central obesity and without central obesity, although statistically the difference was not significant (Farmasi \& Dan, 2015). Determination of central obesity is important because it is associated with insulin resistance, which is the basis for the metabolic syndrome.

Flexibility as the ability to perform movements in the joint space, 
and is also determined by the elasticity of the muscles, tendons and ligaments. Flexibility is the effectiveness of a person in adjusting himself to carry out all body activities with a broad stretch, especially the muscles and ligaments around the joints. Flexibility is the effectiveness of a person in adjusting himself to all activities with stretching the body in a wide area of the joint.

The study entitled "Bad Posture Habits That Interfere with Health of Temporomandibular Joint", the results of this study stated that daily activities that result in wrong posture that last for years cause trauma to the stomatognathic system, especially in the muscles. Muscles and joints are thus a direct cause of STM (Temporomandibular Joint) disorders. Treatment must be done by eliminating etiological factors (Winarti \& Rikmasari, 2011). The study entitled "The Effect of Range of Motion (ROM) Exercise on Knee Joint Flexibility in the Elderly at the Wening Wardoyo Ungaran Nursing Home" The results showed that there was a significant increase between the first-second measurements on flexion of the right and left knee joints between the first-third measurements on flexion of the left knee joint. ROM exercises during the left knee joint can increase flexibility by 350 or $43.75 \%$ (Sarah \& Bambang, 2010).

The study entitled "The agility and ankle flexibility method on dribbling skills", states that flexibility is an individual's ability to make the widest possible movement by involving joints, ligaments and tendons in activities. There are two kinds of flexibility, namely static flexibility and dynamic flexibility. Static flexibility is determined by the size of the range of motion of one joint or several joints. Meanwhile, dynamic flexibility is a person's ability to move at high speed. Factors that affect a person's level of flexibility include the composition of connective tissue, tissue response, muscle elasticity, tendons and ligaments, bone composition, joint shape, body temperature or temperature, age, sex, and biorhythms (Rahayu \& Rustiana, 2017). Several factors influence the incidence of obesity, including:

1. Age, although it occurs at all ages, obesity is often referred to as a disorder in middle age. Obesity that appears in the first year of life in order that the child rapidly becomes large for his age. The research entitled "The Effect of Age on Postural Balance", The results of the study assume that with age the balance decreases, and it should be noted that the further it is divided into several stages and each control of the body is at a different level, the aging of the individual level and its type is very important. on the impact of balance (Pankanin \& Medicum, 2018).

2. Gender, especially in women, is caused by an endocrine effect, because this condition occurs at times of hormonal changes.

3. Social level, obesity is often found in women from poor families because it is difficult to buy foods that are high in protein content and can only afford cheap foods that generally contain a lot of charcoal hydrate. Obesity found among executives or businessmen arises from high fat foods accompanied by the use of alcoholic beverages.

4. Physical activity, obesity is often found in people who do not do physical activity and mostly sit. Increased mechanisms and ease of transportation tend to be less mobile, thus using less energy for daily activities.

5. The most dominant factor associated with the incidence of obesity was education level $(\mathrm{OR}=2.85 ; 95 \% \mathrm{CI}=$ 1,240-6,502). The high prevalence of 
obesity in workers requires more serious attention from the company in overcoming the problem of obesity through efforts to increase communication, information, and nutrition education programs that are more targeted and programmed and it is necessary to conduct socialization to monitor body weight and waist-hip circumference on a regular basis to prevent the onset of coronary heart disease (Christina, Ayu, \& Sartika, 2011).

6. Eating habits, there are different habits in each person in people who are obese. Drinking sugary drinks, preferably in a dose that is not excessive, because it is harmful to the health of the body. Consuming 2 liters of water (clear water) every day is very good for the body. When viewed from the color white water (clear water) looks normal, but water is very meaningful for the health of the body (Lakoro, Hadi, \& Julia, 2016).

7. Psychological factors, economic stability is related to obesity because and can be one of the triggers for Diabetes Mellitus. The impact of solving deep emotional problems is an important protector of those concerned. These circumstances eliminate obesity without providing a satisfactory alternative solution will only exacerbate the problem.

8. Genetic factors, are factors that play a role in the incidence of obesity. The onset of obesity in the family is more determined because of the eating habits in the family concerned and genetic factors that are specific to this kind of incident. The study entitled "Obesity, Causes and Forms of Treatment" The results of this study showed that a combination of diet, exercise and psychological therapy is an effective and safe alternative that can be used to treat obesity, because with a carefully planned diet, energy needs can still be met, exercises with the right dose and selection of exercise models as well as psychological approaches through self-monitoring and Cognitive Behavioral Treatment can be used to treat obesity disorders in a person. In the above case, patients with high discipline in doing therapy can eventually experience weight loss gradually in about three months, their body weight approaches the ideal body weight (Windows, Corporation, Hori, \& Sakajiri, n.d.).

Basically, all types of sports activities can reduce body fat if they are carried out seriously according to a predetermined exercise program, if you do sports half-heartedly you will get results that are not optimal. Intention is a determining factor for someone to actively do sports (Panggraita \& Soenyoto, 2017). In general, obesity can aggravate the disease in several ways: 1 ). Metabolic changes: Due to increased fat, fat cells enlarge and produce a number of chemicals that increase the risk of getting diseases, such as diabetes, hypertension, gallstones, and some types of cancer. 2) Increased mass: increased body weight causes structural disorders that result in cell damage and disease, including osteoarthritis and sleep apnea. 3). Dangerous types of fat cells: fat that is distributed in the abdominal area and upper part of the body causes a higher health risk compared to fat that is spread in the form of pears around the thighs and pelvis (Ngurah et al., 2015).

A fat body makes people lazy to move, while being lazy to move results in small calories used, and unused calories will accumulate and be stored in the sublayer of the skin as fat. Zumba exercises can also reduce body fat, but the progress is slower than aerobic exercise, because the Zumba movements are identical to 
dancing combined with gymnastic movements (Faridah, 2017). The research entitled "Effect of Multimedia-Based Gymnastics Method and Obesity of Fat Reduction at The Waist" The results of the study stated that the method of exercise and obesity can affect the relationship between Body Mass Index and fat percentage, information about obesity is needed to find out how much someone wants to reduce obesity and body fat, especially waist fat, which is the focus. Exercise methods affect physiological conditions, by exercising a person can reduce body fat. Having an obese body for most individuals is a hindrance when doing activities, because it is difficult to move, gasping for breath, even shortness of breath. When the body's condition is trained to exercise to do activities regularly, it allows the fat in the body to decrease, so that the body mass index is also reduced and is in a normal value, balanced with weight loss. One of the sports that is carried out is bodybuilding exercises for women in reproductive age (Faridah \& Ks, 2019). Therefore, with activities that are routinely carried out every day can make the body flexible and not lazy to move wherever and whenever you are even though you have various types of obesity.

\section{METHODS}

The design used in this study is a $2 \times 2$ factorial. It is explained about factorial experiments that what is measured is not only the influence of the main factor of each independent variable on the dependent variable, but also the influence of the interaction between the independent variables. The research design can be described as follows:
Table 1. $2 \times 2$ factorial

\begin{tabular}{ccc}
\hline Attributive Variable & $\begin{array}{c}\text { High } \\
\text { Flexibility } \\
\text { Manipulative Variable }\end{array}$ & $\begin{array}{c}\text { Low } \\
\text { Flexibility } \\
(\mathrm{b} 1)\end{array}$ \\
\hline Pear Obesity $\left(\mathrm{a}_{1}\right)$ & $\mathrm{a}_{1} \mathrm{~b}_{1}$ & $\mathrm{a}_{1} \mathrm{~b}_{2}$ \\
\hline Apple Obesity $\left(\mathrm{a}_{2}\right)$ & $\mathrm{a}_{2} \mathrm{~b}_{1}$ & $\mathrm{a}_{2} \mathrm{~b}_{2}$ \\
\hline
\end{tabular}

With:

a1b1: Group of obese pear type women with high flexibility

a1b2: Group of obese pear type women with low flexibility

a2b1: Group of obese apple type women with high flexibility

a2b2: Group of obese apple type women with low flexibility

\section{Participants}

The population is the whole object that becomes the center of research attention and a place to generalize the research findings. The population in this study is the 50 members of Larasati gymnastics in Semarang, who in productive age women between 30-40 years. The number of samples of 40 people is quite representative (representing) for the large population in this study. The sampling technique in this study was using purposive sampling, which is a sampling technique determined by giving equal opportunity to each member of the population as a sample, namely the number is adjusted to the member of the subject in each group, the experimental group of obesity type pear apple type obesity control group.

\section{Sampling Procedures}

Research variable in this study involved three variables, namely the independent variable, the attributive variable and the dependent variable. Independent variables (independent) 
consist of manipulative variables (obesity type) and attributive variables (flexibility). The dependent variable (dependent) in this study is the decrease in body fat of women in productive age, 30-40 years, members of Larasati gymnastics Semarang.

\section{Procedures}

The data collection technique in this research is to measure flexibility and body fat. Preparation for the implementation of this research and data analysis, all measurement data is required to be collected by measuring using skinfold calipers in the following manner: Measures the amount of fat present in all parts of the body with a benchmark percentage of fat based on measurements. Determining the level of flexibility of mothers with high flexibility and low flexibility categories according to the sit and reach test guidelines.

\section{RESULT}

The descriptions of the results of the data analysis of the results of the body fat tests carried out according to the groups being compared are presented as follows:

Table 2. Data Description of Body Fat Test Results for Each Group Based on the Type of Obesity and Type of Flexibility

\begin{tabular}{|c|c|c|c|c|c|}
\hline $\begin{array}{c}\text { Treatmen } \\
\mathbf{t}\end{array}$ & $\begin{array}{c}\text { Flexibilit } \\
\mathbf{y}\end{array}$ & $\begin{array}{c}\text { Statisti } \\
\text { c }\end{array}$ & $\begin{array}{c}\text { Initial } \\
\text { Test } \\
\text { Result }\end{array}$ & $\begin{array}{c}\text { Final } \\
\text { Test } \\
\text { Result }\end{array}$ & $\begin{array}{c}\text { Body } \\
\text { Fat } \\
\text { Decreas } \\
\text { e } \\
\end{array}$ \\
\hline \multirow{6}{*}{$\begin{array}{c}\text { Pear type } \\
\text { obesity }\end{array}$} & \multirow{3}{*}{ High } & Total & 664.00 & 626.00 & 28.00 \\
\hline & & Average & 66.400 & 62.600 & 2.800 \\
\hline & & SD & 6.336 & 6.121 & 1.619 \\
\hline & \multirow{3}{*}{ Low } & Total & 703.00 & 636.00 & 57.00 \\
\hline & & Average & 70.300 & 63.600 & 5.700 \\
\hline & & SD & 7.693 & 7.897 & 1.889 \\
\hline \multirow{6}{*}{$\begin{array}{l}\text { Apple } \\
\text { type } \\
\text { obesity }\end{array}$} & \multirow{3}{*}{ High } & Total & 683.00 & 614.00 & 59.00 \\
\hline & & Average & 68.300 & 61.400 & 5.900 \\
\hline & & SD & 8.753 & 7.462 & 1.234 \\
\hline & \multirow{3}{*}{ Low } & Total & 658.00 & 593.00 & 55.00 \\
\hline & & Average & 65.800 & 59.300 & 4.500 \\
\hline & & SD & 8.426 & 9.067 & 1.581 \\
\hline
\end{tabular}

The things that get attention from the values listed in the table above are as follows:

1. In the pear obese treatment group had an average of initial test 66,400 and a final test of 62,600 with an average of body fat decrease 2,800 . In the obese treatment group, apples had a initial test of 65,800 and a final test of 59,300 and an average of body fat decrease 5,500 . When the two treatments were compared, the average reduction in body fat with apple obesity treatment was better than pear obesity.

2. The treatment group on subjects with low flexibility had an average initial measurement of 67,350 and a final measurement of 62,000 with a decrease in body fat of 4,350. In the group of subjects who had high flexibility had an average initial measurement of 68,050 and a final measurement of 61,450 with a body fat decrease of 5,600 .

3. When the two groups were compared, the group of subjects with high flexibility had better body fat reduction in average than the group of subjects with low flexibility.

4. In order to obtain a complete picture of the body fat decrease values for each of the main study factors, comparisons need to be made. Each cell (treatment group) has a different body fat decrease. The average value of body fat reduction that reaches each treatment group is presented in the form of a histogram.

An overview of the body fat decrease in each group based on the level of exercise and flexibility can be seen on the histogram as follows: 


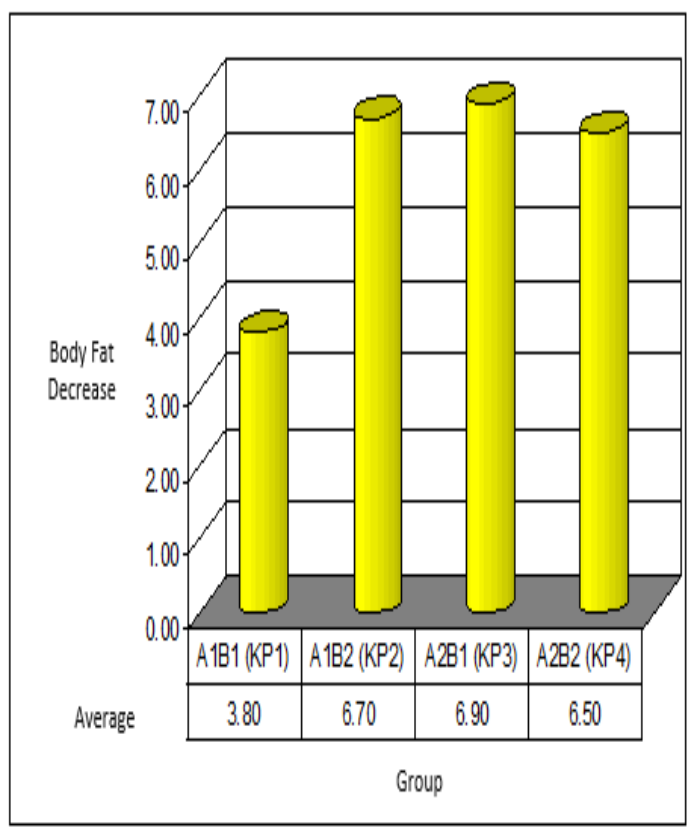

Figure 1. Histogram of Average Body Fat Loss in Each Group Based on the Type of Obesity and Type of Flexibility

The group of women who had the pear type obesity and the apple type obesity had a different in body fat decrease. If the women were compared, it can be seen that the apple type obesity treatment group had a body fat decrease by 1.45 , which was greater than the apple type obesity treatment group.

The difference in the level of flexibility has an effect on decreasing body fat. If the group of women with high flexibility and low flexibility is compared, it can be seen that the group of women who have high flexibility has a body fat decrease by 1.25 , which is greater than the group of women who have low flexibility.

\section{DISCUSSION}

The discussion this study provides a further interpretation of the results of the data analysis that have been stated. Based on hypothesis testing, it resulted in two groups of analysis conclusions, namely: (a) there is a significant difference in the influence between the main research factors (b) there is a significant interaction between the main factors in the form of two-factor interaction. The analysis conclusion group can be further elaborated as follows:

1. Effects of pear type obesity and apple type obesity. Based on testing the first hypothesis, it turns out that there is a significant difference between the group of women who have pear type obesity and apple type obesity in body fat decrease. In the group of women who were obese, apple type obesity had a better decrease in body fat than the group of women who have pear type obesity. From the figures generated in the data analysis, it shows that the ratio of the average decrease in the percentage of body fat produced by apple type obesity is 1.45 greater than that of pear type obesity.

2. The influence between high flexibility and low flexibility. Based on the second hypothesis testing, it turns out that there is a significant effect between groups of women with high flexibility and low flexibility in body fat decrease. In the group of women with high flexibility had a greater body fat decrease than the group of women with low flexibility. From the figures generated in the data analysis, it shows that the ratio of the average body fat decrease levels in women with high flexibility is 1.25 greater than that in the group of women who have low flexibility. Effect of the Interaction Between Obesity and Flexibility From the summary table of the results of the two-factor analysis of variance, it appears that the main research factors in the form of two factors show a real interaction. The interaction between the two research factors can be seen in the following figure: 

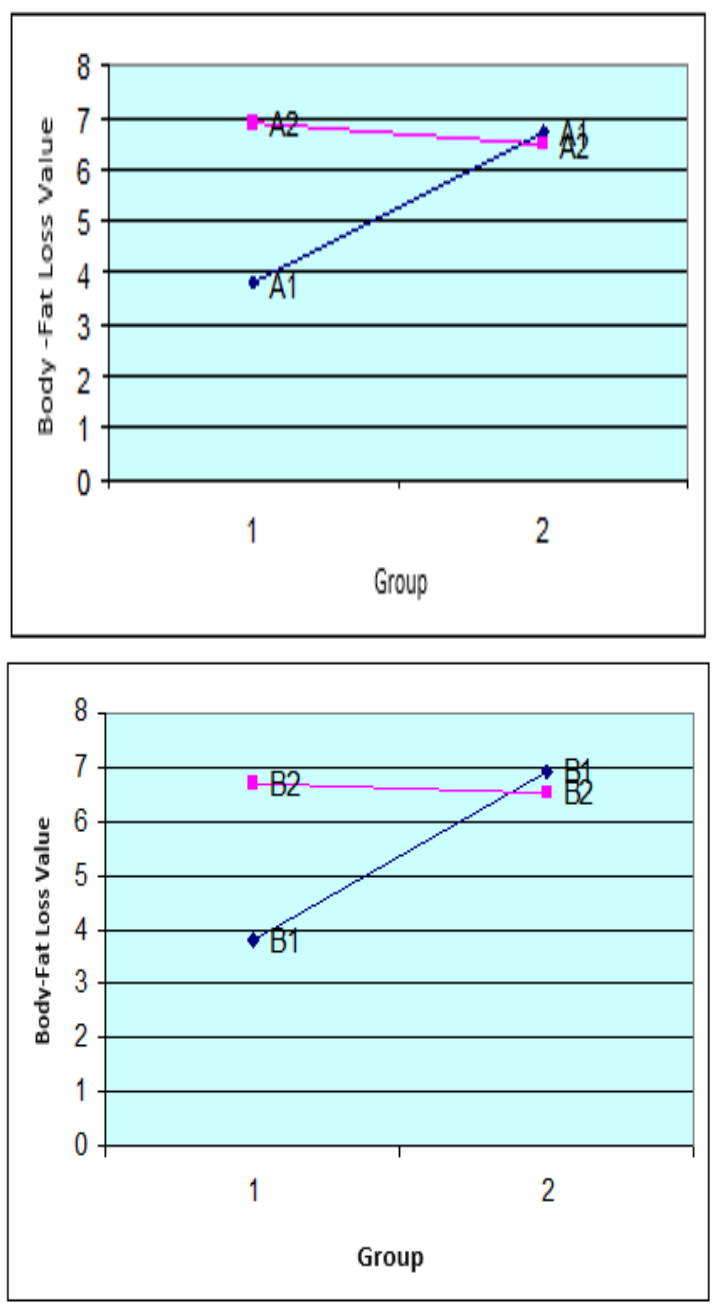

Figure 2. Forms of Interaction Change the Amount of Decline body fat with A1 = Pear type obesity, A2 = Apple type obesity, B1 = High Flexibility, B2 = Low Flexibility

On the basis of the picture above, that the shape of the line of change in the value of body fat is not parallel and crosses. The line of change in body fat loss between groups has a point where it meets or crosses. Between the types of obesity to lower body fat levels and flexibility has a cross point. This means that there is a significant interaction between the two. The figure shows that the type of flexibility has an effect on obesity outcomes. Based on the results of the research achieved, it turns out that women who have high flexibility have a large fat decrease if they have the apple type obesity. Women who have high flexibility with apple type obesity have a better body fat decrease than women with low flexibility and have pear type obesity. Fcount $=6,962>$ Ftable $=3.11$. The effectiveness of which is applied to reduce body fat is influenced by women who have high flexibility and low flexibility type.

\section{CONCLUSION}

Based on the results of the research and data analysis that have been carried out, the following conclusions can be obtained:

1. There is a significant effect between the obesity pear type and obesity apple type in decreasing body fat. The effect of the obesity pear type is better than the obesity apple type on the reduction of body fat. Low flexibility can only reduce body fat slightly, in contrast to high flexibility can reduce more body fat levels.

2. There is a significant effect of decreasing body fat levels between women who have high flexibility and low flexibility. The body fat decrease in women with low flexibility decreased their body fat compared to women with low flexibility with only a slight decrease in body fat. There is a significant interaction between the type of obesity and flexibility in body fat decrease.

a. The group of women who have high flexibility has a large reduction in waist fat levels if you have pear-type obesity.

b. The group of women who had low flexibility had better body fat loss if they had apple-type obesity.

\section{REFERENCES}

Al-Ruthia, Y. S., Al-Mandeel, H., \& Alsanawi, H. (2017). Ovulation 
Induction By Metformin Among Obese Dan Non-Obese Women With Polycystic Ovary Syndrome. Saudi Pharmaceutical Journal, 25(5), 795-800. Https://Doi.Org/10.1016/J.Jsps.201 6.12.001

Christina, D., Ayu, R., \& Sartika, D. (2011). Obesitas Pada Pekerja Minyak Dan Gas Obesity Among Oil And Gas Workers. National Public Health Journal, 6(3), 104110.

Endang, N., Ratu, A., \& Dewi, A. (2010). Faktor Risiko Obesitas Pada Orang Dewasa Urban Dan Rural Obesity Risk Factors In Urban And Rural Adults. Jurnal Kesehatan Masyarakat Nasional, 5, 29-34. Retrieved From Http://Jurnalkesmas.Ui.Ac.Id/Inde x.Php/Kesmas/Article/Download/1 $59 / 160$

Faridah, E. (2017). Aerobic And Zumba Influences For The Upper Arm, Thigh And Waist Size On Mother's Bugar Pancing Medan Club In 2016. International Journal of Science And Research (Ijsr), 6(12), 1151-1153.

Https://Doi.Org/10.21275/6121701

Faridah, E., \& Ks, S. (2019). Effect Of Multimedia-Based Gymnastics Method And Obesity Of Fat Reduction At The Waist. International Journal of Engineering And Advanced Technology, 8(5c), 1039-1043. Https://Doi.Org/10.35940/Ijeat.E1 $147.0585 \mathrm{c} 19$.

Farmasi, J., \& Dan, S. (2015). Kadar Hbalc Dan Rasio Lipid Pada Wanita Dewasa Dengan Obesitas Sentral Lisa Sudaryanto, Laurensius Imus Ventora, Fenty *) Fakultas Farmasi, Universitas Sanata Dharma, Yogyakarta, 12(2), 61-65.
Lakoro, Y., Hadi, H., \& Julia, M. (2016). Pola Konsumsi Air, Susu Dan Produk Susu, Serta Minuman Manis Sebagai Faktor Risiko Obesitas Pada Anak Sekolah Dasar Di Kota Yogyakarta Dan Kabupaten Bantul. Jurnal Gizi Dan Dietetik Indonesia (Indonesian Journal of Nutrition And Dietetics), 1(2),102. Https://Doi.Org/10.21927/Ijnd.201 3.1(2).102-109

Marlinda, L. (2015). Perbandingan Kadar Low Density Lipoprotein (Ldl) Pada Penderita Obesitas Apple Shaped Dan Obesitas Pear Shaped Di Lingkungan Pegawai Negeri Sipil Kantor Kelurahan Kecamatan Tanjung Karang Pusat Kota Bandar Lampung. Universitas Lampung Negeri, 2007, 8-37. Retrieved From Http://Digilib.Unila.Ac.Id/6659/12 5/Bab Ii.Pdf

Panggraita, G. N., \& Soenyoto, T. (2017). Journal Of Physical Education And Sports Pengaruh Latihan Hatha Yoga Dan Kapasitas Vital Paru Terhadap Penurunan Lemak Tubuh Abstrak. Journal of Physical Education And Sports, 6(1), 29-35.

Pankanin, E., \& Medicum, C. (2018). The Influence Of Age On A Postural Balance Scientific Circle At Department Of Hygiene , Epidemiology And Ergonomics ., 8(7), 261-268.

Rahayu, S., \& Rustiana, E. R. (2017). Journal Of Physical Education And Sports Metode Latihan Kelincahan Dan Fleksibilitas Pergelangan Kaki Terhadap Keterampilan Menggiring Bola Abstrak, 6(1), 6671.

Sarah, U., \& Bambang, S. (2010). Pengaruh Latihan Range Of Motion (Rom) Terhadap Fleksibilitas Sendi 
Lutut Pada Lansia Di Panti Wreda Wening Wardoyo Ungaran. Nurse Media: Journal Of Nursing, 1(2), 72-78.

Https://Doi.Org/10.14710/Nmjn.V $1 \mathrm{i} 2.718$

S, E., Arhana, B., Suandi, I., \& Sidiartha, I. (2017). Obesitas Sebagai Faktor Risiko Sindrom Syok Dengue. Sari Pediatri, $\quad 11(4), \quad 238$. Https://Doi.Org/10.14238/Sp11.4.2 009.238-43

Van De Maele, K., Devlieger, R., \& Gies, I. (2018). In Utero Programming And Early Detection Of Cardiovascular Disease In The Offspring Of Mothers With Obesity. Atherosclerosis, 275, 182195.

Https://Doi.Org/10.1016/J.Atheros clerosis.2018.06.016

Winarti, T. M., \& Rikmasari, R. (2011). Kebiasaan Postur Tubuh Yang Buruk Yang Mengganggu Kesehatan Sendi Temporomandibula Bad Posture Habits That Interfere With Health Of Temporomandibular Joint. Journal of Dentomaxillofacial Science, $10(3), \quad 196$. Https://Doi.Org/10.15562/Jdmfs.V 10i3.284 